\title{
Verticillium dahliae Infects, Alters Plant Biomass, and Produces Inoculum on Rotation Crops
}

\author{
D. L. Wheeler and D. A. Johnson
}

Department of Plant Pathology, Washington State University, Pullman 99164-6430.

Accepted for publication 27 January 2016.

\begin{abstract}
Wheeler, D. L., and Johnson, D. A. 2016. Verticillium dahliae infects, alters plant biomass, and produces inoculum on rotation crops. Phytopathology 106:602-613.

Verticillium wilt, caused by Verticillium dahliae, reduces yields of potato and mint. Crop rotation is a potential management tactic for Verticillium wilt; however, the wide host range of V. dahliae may limit the effectiveness of this tactic. The hypothesis that rotation crops are infected by $V$. dahliae inoculum originating from potato and mint was tested by inoculation of mustards, grasses, and Austrian winter pea with eight isolates of $V$. dahliae. Inoculum density was estimated from plants and soil.

Typical wilt symptoms were not observed in any rotation crop but plant biomass of some crops was reduced, not affected, or increased by infection of specific isolates. Each isolate was host-specific and infected a subset of the rotation crops tested but microsclerotia from at least one isolate were observed on each rotation crop. Some isolates were hostadapted and differentially altered plant biomass or produced differential amounts of inoculum on rotation crops like arugula and Austrian winter pea, which supported more inoculum of specific isolates than potato. Evidence of asymptomatic and symptomatic infection and differential inoculum formation of $V$. dahliae on rotation crops presented here will be useful in designing rotations for management of Verticillium wilt.
\end{abstract}

Potato (Solanum tuberosum L.) and mint (Mentha spp. L.) are economically valuable crops in the Pacific Northwest (Washington, Oregon, and Idaho) of the United States. Both crops are grown extensively in this region where potato yields account for $58 \%$ of nationwide production (hundredweight) and mint yields account for $85 \%$ of nationwide production (pounds) (NASS 2015). Fields planted with potato and mint may or may not be rotated with each other and other crops such as mustards, grasses, and legumes. Verticillium dahliae Kleb. causes the vascular disease Verticillium wilt on potato, in which it can reduce yields up to 50\% (Powelson and Rowe 1993), and mint, in which it causes stand decline (Dung et al. 2010). Expression of disease symptoms varies among hosts but generally includes stunting, wilting, and premature senescence (Horner 1954; Isaac and Harrison 1968).

V. dahliae can persist in soil for at least 14 years as multicellular, melanized microsclerotia (Wilhelm 1955). Microsclerotia germinate in response to plant root exudates (Emmaty and Green 1969; Mol 1995a), hyphae penetrate root tips (Perry and Evert 1983; Schreiber and Green 1963) and colonize the root cortex and vasculature (Klosterman et al. 2009). Conidia, which are generally produced in response to the host initiating inflorescence development, move acropetally through the xylem vessels and occlude perforation plate apertures and restrict evapotranspiration (Buckley et al. 1969; Eynck et al. 2007). Microsclerotia develop during senescence in all tissues, including vascular, cortical (Isaac and Harrison 1968) and epidermal tissues of potato stems, leaves, petioles, stolons (Mol and Scholte 1995; Slattery 1981), and in epidermal, cortical, and phloem tissues of roots (Perry and Evert 1984). Microsclerotia are returned to the soil by incorporation of crop residue and decomposition of infested plants.

Corresponding author: D. L. Wheeler; E-mail address: david.wheeler@wsu.edu

*The $\boldsymbol{e}$-Xtra logo stands for "electronic extra" and indicates that two supplementary tables are published online.

http://dx.doi.org/10.1094/PHYTO-07-15-0174-R

(C) 2016 The American Phytopathological Society
Available practices to manage Verticillium wilt of potato include host resistance, sanitation, irrigation management, and fumigation (Johnson and Dung 2010), but fumigation is not consistently economical in potato production systems and options are increasingly limited by regulatory restrictions. Crop rotation is another practice that has been actively investigated for management of Verticillium wilt (Bhat and Subbarao 1999; Davis et al. 1996; Easton et al. 1992; Huisman and Ashworth 1976; Joaquim et al. 1988; Larkin et al. 2011; Njoroge et al. 2009; Xiao et al. 1998). V. dahliae, however, causes wilt in over 200 dicotyledonous hosts (Pegg and Brady 2002) and thus poses significant challenges in the development of crop rotations. Additionally, V. dahliae asymptomatically infects a range of other hosts, including both monocotyledonous and dicotyledonous plants (Benson and Ashworth 1976; Evans and Gleeson 1973; Krikun and Bernier 1987; Lacy and Horner 1966; Malcolm et al. 2013; Malik and Milton 1980; Martison and Horner 1962; Mol 1995b; Mol et al. 1995; Vargas-Machuca et al. 1987; Woolliams 1966). Despite the wide host range of $V$. dahliae, variability among isolates exists and some isolates are host-specific and infect a subset of the host range of the species (Bhat and Subbarao 1999), and or host-adapted and are more aggressive and produce more inoculum on a subset of the host range than other isolates (Douhan and Johnson 2001). Hence, to design crop rotations that minimize the development and persistence of $V$. dahliae inoculum in potato fields, the asymptomatic host range of $V$. dahliae and the potential inoculum production on various rotation crops requires investigation.

Identification of rotation crops that serve as asymptomatic hosts for $V$. dahliae and quantification of the potential inoculum from rotation crops may also help resolve or account for discrepancies about the efficacy of crop rotation on Verticillium wilt in published literature. Specific sources of conflicting results reported in the literature include: crop yield in $V$. dahliae-infested fields (Butterfield et al.1978; Davis et al. 1996, 2010a, b; Easton et al. 1992; Larkin et al. 2011; MacGuidwin et al. 2012; Ochiai et al. 2007; O'Sullivan 1978; Subbarao et al. 1999, 2007; Wiggins and Kinkel 2005), incidence of Verticillium wilt (Butterfield et al. 1978; Davis et al. 1996, 2010a, b; Larkin et al. 2010, 2011; Ochiai et al. 2007; Shetty et al. 2000; Subbarao et al. 1999, 2007; Wiggins and 
Kinkel 2005; Xiao et al. 1998), incidence of stems infected with V. dahliae (Davis et al. 2010a; Easton et al. 1992; MacGuidwin et al. 2012; Ochiai et al. 2007; Xiao et al. 1998), and soil inoculum density (Davis et al. 1996, 2010a, b; Easton et al. 1992; Larkin et al. 2011; MacGuidwin et al. 2012; Njoroge et al. 2009; Ochiai et al. 2007; Subbarao et al. 1999, 2007; Xiao et al. 1998).

The overall objective of this study was to test the hypothesis that isolates of $V$. dahliae that incite disease on potato, mint, and other commercial crops can infect rotation crops of potato and mint. Corollary objectives were to (i) determine if microsclerotia are produced on infected rotation crops and estimate inoculum density in stems, roots, and soil of infected rotation crops, (ii) estimate the effects of $V$. dahliae infection on rotation crop symptom development and biomass, and (iii) estimate the incidence of infected stems of rotation crops from commercial fields with a history of Verticillium wilt of potato or mint.

\section{MATERIALS AND METHODS}

Two experiments were conducted to estimate the inoculum density of $V$. dahliae from rotation crops of potato and mint. The experiments differed in experimental design, specifically in the number and species of rotation crop and the number and origin of isolates, the number of replicates per treatment, the density of inoculum used to infest growth media, the type of growth media, the duration of the experiments, and the data collected.

Estimation of the incidence of infected stems and inoculum density of two isolates of $V$. dahliae from roots and soil of two brown mustards, white mustard, sweet corn, spring wheat, and sudangrass. A greenhouse experiment was conducted to determine if rotation crops are infected by isolates of $V$. dahliae from potato and peppermint. The experimental design was comprised of a two-way factorial treatment structure, with six rotation crops and three primary crops crossed with two isolates and one noninfested control. Rotation crops were white mustard 'Martigena' (Sinapis alba L.), brown mustards 'Pacific Gold' and ISCI 99 (Brassica juncea L.), sweet corn 'Marvel' (Zea mays L.), spring wheat 'Alpowa' (Triticum aestivum L.), and sudangrass 'Piper' (Sorghum drummondii Nees ex Steud.). Primary crops were potato 'Norkotah', native mint (Mentha spicata L.), and peppermint 'Black Mitcham' (M. $\times$ piperita L.). Isolates of $V$. dahliae used to infest soil were originally isolated from potato (653) or mint (111) (Table 1). Experimental and observational units consisted of potted plants. Pots were arranged in a randomized complete block design structure with three replicates. Three replicates were used because space for more replicates was not available. Each block was arranged on a separate greenhouse bench oriented parallel to a light gradient. The trial was balanced and repeated once in 2012 . Photoperiods ranged between 12 to $15 \mathrm{~h}$ /day and were not supplemented with additional light. Daytime temperatures ranged between 13 to $29^{\circ} \mathrm{C}$ and the mean daytime temperature was $22^{\circ} \mathrm{C}$. Nighttime temperatures ranged between 11 to $27^{\circ} \mathrm{C}$ and the mean nighttime temperature was $17^{\circ} \mathrm{C}$.

Inoculum was prepared from single conidial isolates of $V$. dahliae cultured in Czapek-Dox broth (MP Biomedicals, Solon, $\mathrm{OH}$ ) on a rotary shaker at $125 \mathrm{rpm}$ for 7 days at $22^{\circ} \mathrm{C}$. Liquid cultures were mixed with $700 \mathrm{ml}$ of sand (grain size between 0.6 and $2.4 \mathrm{~mm}$ ) in 1-liter flasks, and flasks were agitated to distribute propagules throughout the sand. Infested sand was distributed over the surface of a $33 \times 22 \times 5 \mathrm{~cm}$ Pyrex (Pyrex, Charleroi, PA) pan lined with two layers of paper towels, one layer of aluminum screen with $1.4 \mathrm{~mm}$ openings, one layer of Mira cloth (EMD Chemicals, San Diego, $\mathrm{CA}$ ), and dried in a laminar flow hood for 7 days. Dried sand was stored at $22^{\circ} \mathrm{C}$ for 4 weeks to air dry mycelia and conidia (Butterfield and DeVay 1977; Galanopoulos and Tribe 1974).

Inoculum density was estimated from 10 samples of $0.1 \mathrm{~g}$ of sand inoculum uniformly distributed across the surface of plastic Petri dishes $(100 \times 15 \mathrm{~mm})$ containing NP-10 media (Goud and Termorshuizen 2003; Kabir et al. 2004). Sand was rinsed from the surface of the media $48 \mathrm{~h}$ later and colonies were counted with a Nikon SMZ800 dissecting microscope at 10 to $40 \times$ (Nikon Corp., Tokyo).

Growth media was infested with approximately 30 colony-forming units (CFU)/g of each $V$. dahliae isolate by mixing 3,000 $\mathrm{g}$ of Sunshine L2 soilless potting media (Sun Gro Horticulture, Agawam, MA) with $3 \mathrm{~g}$ of sterilized sand or sand infested with 30,000 CFU/g of $V$. dahliae 653 or 111. Growth medium to be planted with Mentha spp. were fertilized with $500 \mathrm{ml}$ of $1.5 \mathrm{~g}$ 24-8-16 N-P-K/3.79 liters of water (Scotts Miracle Grow Company, Marysville, $\mathrm{OH}$ ), whereas media for all other crops were fertilized with $13 \mathrm{~g}$ of 16-16-16 N-P-K fertilizer (Agriliance Agronomy Co., St. Paul, MN).

Plant propagules were tested for $V$. dahliae infection and infestation before planting. Basal-end sections approximately $15 \mathrm{~mm}$ diameter were aseptically excised from potato seed tubers, disinfested in $0.5 \% \mathrm{NaOCl}$ for $3 \mathrm{~min}$, rinsed in sterilized distilled water for $1 \mathrm{~min}$, dried on sterile paper towels, and placed on NP-10. Samples of 50 seed of each plant except potato and both mint species were disinfested for $1 \mathrm{~min}$ in $0.5 \% \mathrm{NaOCl}$, rinsed in sterilized distilled water for $1 \mathrm{~min}$, dried on sterile paper towels, and placed on NP-10. Tuber sections and seed were incubated in the dark for 5 weeks at $22^{\circ} \mathrm{C}$ and then scanned for $V$. dahliae colonies with a dissecting microscope. Candidate $V$. dahliae colonies were identified by the presence of microsclerotia and conidiophore morphology (Inderbitzin et al. 2011a). Only tubers and seed sources not infected or not infested with $V$. dahliae were used in experiments. Rooted cuttings of both mint species derived from $V$. dahliae-free stock plants were used. Stock plants were tested for $V$. dahliae by incubating sterilized stem sections on NP-10 and observing cultures for the presence of $V$. dahliae. Plants were planted in $15.2 \times 17.8 \mathrm{~cm}, 3$ liter pots (J. M. McConkey \& Co., Inc., Sumner, WA).

Two 1-cm sections were sampled from stems 3 (lower) and 30 (upper) $\mathrm{cm}$ above the soil surface after the end of the season for the mint species or after plant senescence for all other species. Stem sections were disinfested for $3 \mathrm{~min}$ in $0.5 \% \mathrm{NaOCl}$ and then rinsed for $1 \mathrm{~min}$ in distilled water, dried on sterile paper towels, and placed on NP-10. Stems were incubated in the dark for 5 weeks at $22^{\circ} \mathrm{C}$ and then scanned for $V$. dahliae colonies as described previously. Mean incidence of infected stems was calculated by averaging the incidence of infected subsamples within each replicate. Subsamples

TABLE 1. Eight isolates of Verticillium dahliae from various hosts, vegetative compatibility groups (VCG), multilocus haplotypes, and mating types used to inoculate rotation crops (from Dung et al. 2013)

\begin{tabular}{lllccccc}
\hline V. dahlia isolate & \multicolumn{1}{c}{ Host } & VCG & Multilocus haplotype & MAT idiomorph & State & Year & Source \\
\hline 653 & Potato & 4A & H04 & MAT1-2 & ID & 1995 & R. Rowe \\
49.B.2010 & Potato & 4B & H07 & MAT1-2 & OR & 2010 & J. Dung \\
111 & Peppermint & 2B & H02 & MAT1-2 & WA & 1996 & D. Johnson \\
155 & Peppermint & 4A & H04 & MAT1-2 & ID & 1996 & D. Johnson \\
461 & Tomato & 2 & H37 & MAT1-1 & OH & 1984 & R. Rowe \\
VMD-4 & Tomato & 2A/B & H38 & MAT1-2 & NY & Pre-1983 & M. Lacy \\
VD5 VSP699 & Spinach & 2B/4B & H07 & MAT1-2 & WA & 2001 & L. du Toit \\
381 & Watermelon & 2A/B & H24 & MAT1-2 & OH & S. Miller \\
\hline
\end{tabular}


values were averaged into sample values to reduce variability across estimates of stem incidence.

Roots were removed from growth media, rinsed with water, and dried in paper bags for 5 weeks at $22^{\circ} \mathrm{C}$ before further processing. Ten roots were subsampled from each root mass. Two, $3-\mathrm{cm}-\mathrm{long}$ root sections were selected from each subsample, 3 and $15 \mathrm{~cm}$ below the plant crowns. Root sections were disinfested with $0.5 \% \mathrm{NaOCl}$ for $3 \mathrm{~min}$, rinsed in distilled water for $1 \mathrm{~min}$, dried on sterilized paper towels and placed onto NP-10. Roots were incubated in the dark for 5 weeks at $22^{\circ} \mathrm{C}$ and then scanned for $V$. dahliae colonies as described previously. Mean root inoculum density (CFU/60 cm of root) was calculated by summing CFU/30 $\mathrm{cm}$ of root and averaging all subsamples within each replicate.

Five $15 \times 110 \mathrm{~mm}$ diameter soil cores were collected from pots containing growth media. Subsamples were homogenized with a mortar and pestle and stored for 5 weeks at $22^{\circ} \mathrm{C}$ to air dry mycelia and conidia (Butterfield and DeVay 1977; Galanopoulos and Tribe 1974). Five subsamples of $0.1 \mathrm{~g}$ were distributed across the surface of Petri dishes containing NP-10 as described by Goud and Termorshuizen (2003). Cultures were incubated in the dark for 14 days at $22^{\circ} \mathrm{C}$. Soil was rinsed from the surface of each plate and colonies of $V$. dahliae were counted. Mean soil inoculum density (CFU/g of soil) was calculated by averaging subsamples within each replicate.

Estimation of inoculum density of eight isolates of $V$. dahliae from stems, roots, and soil of arugula, Austrian winter pea, sweet corn, barley, and sudangrass. A greenhouse experiment was conducted to determine if rotation crops not tested in the proceeding experiment and planted regionally are infected by and serve as inoculum reservoirs of an expanded set of isolates of $V$. dahliae. The experimental design was comprised of a two-way factorial treatment structure, with five rotation crops and two primary crops crossed with eight isolates. Rotation crops were Austrian winter pea (Pisum sativum L.), arugula 'Nemat' (Eruca sativa Mill.), sweet corn, barley 'Baroness' (Hordeum vulgare L.), and sudangrass. Primary crops were potato and peppermint. Isolates of $V$. dahliae used to infest soil are listed in Table 1 and differed in the crops from which they were isolated, vegetative compatibility groups (VCG), multilocus haplotypes, and mating type (Dung et al. 2013). A noninfested control was included. Experimental and observational units consisted of potted plants. Pots were arranged in a randomized complete block design structure with five replicates. Each block was arranged on a separate greenhouse bench oriented parallel to a light gradient. The trial was balanced and repeated once in 2014. Photoperiod, daytime and nighttime temperatures were the same as the experiment with two isolates of $V$. dahliae.

Inoculum and plant propagules were prepared as described above unless indicated otherwise. Growth media was infested as described above but inoculum density was less in this experiment. Growth media was infested with approximately $10 \mathrm{CFU} / \mathrm{g}$ of each $\mathrm{V}$. dahliae isolate by mixing 3,000 g of sterilized sand (grain size between 0.6 and $5 \mathrm{~mm}$ ) with $30 \mathrm{~g}$ of sterilized sand or sand infested with $1,000 \mathrm{CFU} / \mathrm{g}$ of each isolate of $\mathrm{V}$. dahliae. Plants were sown in pots with or without infested sand $24 \mathrm{~h}$ later. Fertilizer (100 ppm of $\mathrm{N}$ Peter's Professional 20-10-20 N-P-K peat-lite special [Everris International B.V., Geldermalsen, The Netherlands]) was applied daily with irrigation.

Senescence and symptom expression of rotation crops were monitored after plant emergence and weekly thereafter until harvest. Percentage of whole plants exhibiting chlorosis, necrosis, and stunting were visually estimated on a weekly basis. Area under the senescence progress curve (AUSPC) was calculated for each treatment (Shaner and Finney 1977). Plant height, measured from the soil surface to the tallest plant tissue, and biomass of dried stems, seed, and roots were measured after harvest.

Stems were sampled from 3 and $19 \mathrm{~cm}$ above the soil surface and assayed for $V$. dahliae as previously described. The $15 \mathrm{~cm}$ stem sections remaining after two subsamples were collected were stored in the dark for 5 weeks at $22^{\circ} \mathrm{C}$ to dry mycelia and conidia (Butterfield and DeVay 1977; Galanopoulos and Tribe 1974). Both dried stems and whole root masses were ground in a coffee grinder (Kitchen Aid, St. Joseph, MI) for $90 \mathrm{~s}$. Five subsamples of $0.1 \mathrm{~g}$ were uniformly distributed across the surface of Petri dishes containing NP-10 and incubated in the dark for 14 days at $22^{\circ} \mathrm{C}$. Stem and root debris were subsequently washed from media surface and colonies of $V$. dahliae were counted. Soil samples were harvested and assayed for $V$. dahliae as previously described. Mean stem, root, and soil inoculum density (CFU/g) were calculated by averaging subsamples within each replicate.

Stem samples were also visually inspected for the presence of $V$. dahliae microsclerotia with a dissecting microscope at $25 \times$. Candidate V. dahliae microsclerotia were excised from stem tissue, observed and photographed with an Olympus BX53 compound microscope (Olympus America Inc., Center Valley, PA). Microslcerotia were placed on NP-10, incubated in the dark for 14 days at $22^{\circ} \mathrm{C}$ and then observed weekly for $V$. dahliae microsclerotia and conidiophores.

Seed from arugula, Austrian winter pea, sweet corn, barley, and sudangrass were harvested and tested for V. dahliae contamination. Seed were disinfested with $95 \%$ ethanol, rinsed for $3 \mathrm{~min}$ in $0.5 \%$ $\mathrm{NaOCl}$ and then $1 \mathrm{~min}$ in distilled water, dried on sterile paper towels, and placed on NP-10. Seed were incubated in the dark for 5 weeks at $22^{\circ} \mathrm{C}$ and then scanned for $V$. dahliae colonies as described previously.

Detection of Verticillium spp. in commercial fields. A stratified random sample design was used to collect stems from each field (Cochran 1977). Wheel tracks in center pivot fields were used to delineate strata and samples were randomly collected within each stratum. Sampling was completed during the growing seasons in 2013 and 2014. Stems of white mustard, brown mustard 'ISCI 99', arugula, sunflower (Helianthus annuus L.), pea (P. sativum L.), timothy (Phleum pratense L.), bean (Phaseolus vulgaris L.), dill (Anethum graveolens L.), buckwheat (Fagopyrum esculentum Moench), sweet corn, wheat, barley, oats, and proso millet (Panicum miliaceum L.) were collected from 21 commercial fields with a history of Verticillium wilt of potato or mint in the Columbia River Basin in central Washington. In two fields brown mustard and millet or brown mustard and wheat were growing together and both rotation crops were collected. Stems were assayed for $V$. dahliae as previously described for the first greenhouse experiments. Mean incidence of infected stems was calculated within each crop from one field.

Identification of isolates collected from rotation crops in fields with a history of Verticillium wilt. Isolates were identified to genus and, tentatively until sequencing, to species using morphological features including the presence or absence of yellow pigmentation, verticilliate conidiophores, phialidic conidiogenous cells, cylindrical and hyaline conidia, and resting structure morphology as described in the key published by Inderbitzin et al. (2011a).

Single conidia of isolates of Verticillium spp. were subcultured on potato dextrose agar (PDA) media overlaid with two layers of dialysis membrane (Spectrum Laboratories, Rancho Dominguez, CA). Cultures were incubated for 10 to 15 days at $22^{\circ} \mathrm{C}$ and mycelia was collected and lyophilized before DNA extraction. Genomic DNA was extracted with a glass bead breakage method (Dobinson 1995) and DNA quality and quantity were measured with spectrophotometry and agarose gel electrophoresis of samples and known lambda DNA standards.

DNA sequences from translation elongation factor 1 alpha $(E F 1-a)$, glyceraldehyde-3-phosphate $(G P D)$, actin $(A C T)$, and tryptophan synthase $(T S)$ were amplified with the primers and polymerase chain reaction (PCR) assays described by Inderbitzin et al. (2011a). Purified PCR products were obtained by adding $2 \mu$ l of ExoSAP-IT (USB Corporation, Cleveland, $\mathrm{OH}$ ) to $5 \mu \mathrm{l}$ of sample and incubating samples at $37^{\circ} \mathrm{C}$ for $15 \mathrm{~min}$ and $80^{\circ} \mathrm{C}$ for $15 \mathrm{~min}$. PCR products were sequenced in forward and reverse directions by Eurofins Genomics (Eurofins MWG Operon, Louisville, KY) using cycle sequencing 
technology on a ABI 3730XL machine (Applied Biosystems, Foster City, CA). Sequence data were aligned and, using chromatograms, flanking regions with low signal and mixed peaks were trimmed in Geneious r8 (Biomatters Inc., San Francisco, CA). BLAST queries were completed against reference strains from Inderbitzin et al. (2011a, b) in GenBank (Altschul et al. 1997). Two isolates from every infected crop within each field and one isolate from one corn field were identified with DNA sequence data. In total, 19 isolates from 10 rotation crops collected from 8 of the 21 sampled fields were sequenced.

Data analyses. Count data of CFU per unit of substrate from the experiments described herein were zero-inflated (contained numerous 0 values), ranged several orders of magnitude from 0 to 1,000 , were generally not normally distributed, and exhibited mild to acute heteroscedasticity. Therefore, data did not satisfy assumptions necessary for parametric analyses like analysis of variance (ANOVA) and some remedial transformations are not always biologically interpretable or justifiable (O'Hara and Kotze 2010). To our knowledge, no nonparametric analyses are available that support count data from a multifactorial treatment structure and permit tests of interaction terms. For generalized linear mixed models (GLMMs), a single distribution must be specified for the data (Bolker et al. 2009); however, multiple distributions were observed among the count data in this study. Therefore, an analytical method invariant to the characteristics of data described above and permissive to hypothesis testing across categorical groups of fixed and random independent variables in multifactorial designs was required.

Permutational multivariate analysis of variance (PERMANOVA) was developed for testing ecological hypotheses with data that do not satisfy parametric assumptions and experimental designs (e.g., factorial) that are not accommodated by nonparametric analyses (Anderson 2001). Like ANOVA, PERMANOVA compares variation within and among groups by constructing test statistics, termed pseudo- $F$ statistics, from ratios of squared distances within and among groups (Anderson 2001). Unlike ANOVA, PERMANOVA partitions total sums of squares from resemblance matrices, not raw or transformed data, and computes $P$ values by permutation. The assumption of normality requisite for traditional ANOVA is alleviated by calculating $P$ values for hypothesis tests, not under an assumed distribution, but by comparing the original pseudo- $F$ statistic to those under the empirical null distribution generated by permutation of factor labels (Anderson 2001). Interpretation of the test statistic is the same for ANOVA when the analysis includes one dependent variable (Anderson 2001). Finally, PERMANOVA assumes independence of observations and does not differentiate between differences in location and dispersion, thus tests for heteroscedasticity are requisite before interpretation of results (Anderson 2001).

PERMANOVA was used herein to test the null hypotheses that the incidence of infected stems and inoculum density from stems, roots, and soil were not different among or within crops. All variables

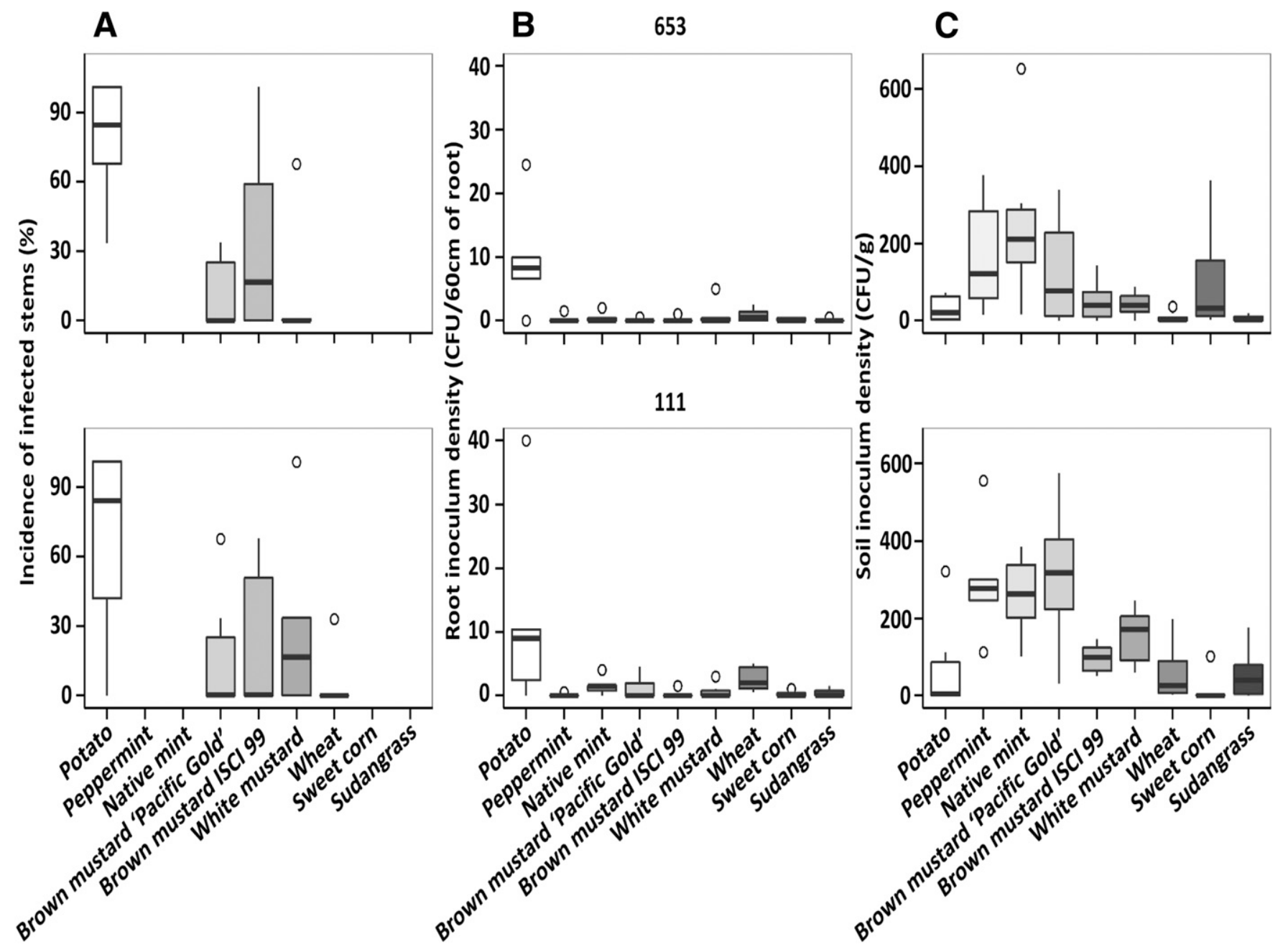

Fig. 1. Inoculum density of two isolates of Verticillium dahliae from stems, roots, and soil of two brown mustards, white mustard, sweet corn, spring wheat, and sudangrass. A, Incidence of infected stems (\% of infected stems), B, root inoculum density (CFU/60 cm of root), and C, soil inoculum density (CFU/g of soil) detected from crops grown in soil infested with V. dahliae isolates 653 and 111 are presented as boxplots. Boxplot hinges represent 1st and 3rd quartiles, whiskers extend to values within $1.5 \times$ the interquartile range, and circles represent outliers. 
from all experiments, except plant biomass data, were fourth-root transformed prior to analyses to scale observations to similar orders of magnitude. Bray-Curtis similarity matrices with zero-adjusted Bray-Curtis coefficients that possess desirable properties for zeroinflated data sets (Clarke et al. 2006) were generated to accommodate zero-inflated inoculum density data. PERMANOVA was used to model the incidence of infected stems and inoculum density from stems, roots, and soil as a function of crops, isolates, blocks, trials, and all relevant interactions. Crop and isolate were treated as fixed effects while trial and block were treated as random effects. $P$ values for each model term were calculated as described by Anderson (2001) with 9,999 permutations. The null hypothesis of homoscedasticity within crops and isolates was tested and not rejected since all $P$ values were $P \geq 0.08$.

Pairwise comparisons among crops were completed within each isolate. Monte Carlo sampling was used to calculate $P$-values for pairwise comparisons since the number of unique permutations was less than 100 (Anderson et al. 2008). The false discovery rate was controlled by adjusting $P$ values with the Bonferroni-type procedure (Benjamini and Hochberg 1995; Glickman et al. 2014) using the "p.adjust" function in R. Since no significant two or three way interactions between crop and trial, isolate and trial, and crop, isolate, and trial were detected $(P \geq 0.1)$, data from both trials for each experiment were combined for analysis. PERMANOVA was completed in PRIMER 7 (Plymouth Routine In Multivariate Ecological Research) (2015 PRIMER-E Ltd., Lutton, Ivybridge, UK). Before PERMANOVA was used, data from both experiments were analyzed with ANOVA after $\log (x+1)$ transformation. Both ANOVA and PERMANOVA analyses converged on similar results; however, PERMANOVA results are presented because of the reasons outlined above.

Patterns in total inoculum density from stems, roots, and soil of crops in the experiment with eight isolates of $V$. dahliae were recognized with nonmetric multidimensional scaling (NMDS). Inoculum density data from stems, roots, and soil was used to provide a holistic representation of the total inoculum contributed

TABLE 2. Permutational multivariate analysis of variance (PERMANOVA) tables for the incidence of infected stems, root inoculum density, and soil inoculum density of two isolates of Verticillium dahliae estimated from two brown mustards, white mustard, sweet corn, spring wheat, sudangrass, potato, peppermint, and native mint

\begin{tabular}{lrrrr}
\hline Source of variation & df & Sum of squares & Pseudo- $F$ & $P($ perm) \\
\hline Incidence of infected stems & & & & \\
Crop & 8 & $10,801.00$ & 7.80 & 0.0074 \\
Isolate & 1 & 22.53 & 0.59 & 0.5036 \\
Block & 2 & 137.64 & 0.79 & 0.4650 \\
Trial & 1 & 53.79 & 0.22 & 0.6930 \\
Crop $\times$ isolate & 8 & 258.87 & 0.66 & 0.7075 \\
Crop $\times$ trial & 8 & $1,383.20$ & 0.68 & 0.7604 \\
Isolate $\times$ trial & 1 & 37.73 & 0.43 & 0.5115 \\
Crop $\times$ isolate $\times$ trial & 8 & 386.88 & 0.55 & 0.8179 \\
Root inoculum density & & & & \\
Crop & 8 & $12,363.00$ & 2.15 & 0.1583 \\
Isolate & 1 & 866.21 & 36.63 & 0.2432 \\
Block & 2 & 71.46 & 0.15 & 0.8757 \\
Trial & 1 & 35.96 & 0.15 & 0.7273 \\
Crop $\times$ isolate & 8 & $1,625.80$ & 0.72 & 0.6716 \\
Crop $\times$ trial & 8 & $2,750.00$ & 0.81 & 0.6242 \\
Isolate $\times$ trial & 1 & 23.64 & 0.10 & 0.7853 \\
Crop $\times$ isolate $\times$ trial & 8 & $2,236.30$ & 1.22 & 0.2948 \\
Soil inoculum density & & & & \\
Crop & 8 & $17,052.00$ & 6.62 & 0.0064 \\
Isolate & 1 & $1,235.30$ & 405.09 & 0.2407 \\
Block & 2 & $2,001.00$ & 2.41 & 0.0785 \\
Trial & 1 & 122.61 & 0.29 & 0.6747 \\
Crop $\times$ isolate & 8 & $8,614.80$ & 5.67 & 0.0073 \\
Crop $\times$ trial & 8 & $2,572.40$ & 0.77 & 0.6483 \\
Isolate $\times$ trial & 1 & 3.04 & 0.01 & 0.9938 \\
Crop $\times$ isolate $\times$ trial & 8 & $1,519.30$ & 0.45 & 0.9296 \\
\hline
\end{tabular}

by each crop. Unlike other distance-based ordination techniques, NMDS does not assume and maximize linear correlations among variables but instead minimizes stress, the difference between distances from a resemblance matrix and ordination space, by maximizing rank-order correlations (Clarke 1993; Legendre and Legendre 1998; McCune and Grace 2002). Interpretation of NMDS biplots does not depend on the order, scale, and direction of the axes (Legendre and Legendre 1998) but instead depends on the proximity between points, where close points are more similar to each other than distant points (Kruskal 1964). A Bray-Curtis similarity matrix was generated and NMDS was performed with the "metaMDS" function in the "vegan" package (Oksanen et al. 2013) in R (version 3.2.1, R Foundation for Statistical Computing, Austria). A twodimensional ordination biplot is presented since stress was $<0.1$, indicating distances in ordination space are representative of original dissimilarities between inoculum density estimates from rotation crops (Clarke 1993; McCune and Grace 2002), and decreased insubstantially in higher dimensional space (Legendre and Legendre 1998).

Biomass data from the experiment with eight isolates of V. dahliae were analyzed with ANOVA. Each factor was treated and tested for interactions as previously mentioned. ANOVA for dried stem and root weight was computed with PROC MIXED in SAS (version 9.2; SAS Institute, Cary, NC). Quantile-quantile plots and Shapiro-Wilks tests were used to diagnose and test for normality. The null hypothesis of normally distributed residuals was tested and not rejected for stem $(P=0.08)$ and root weight $(P=0.1)$ data. Homoscedasticity was tested and rejected for stem $(P=0.04)$ and root weight $(P=0.03)$ with the Breusch-pagan test. Biomass data were therefore $\log$ transformed prior to analyses to stabilize variances of stem and root weight distributions. Post hoc comparisons among cell means were performed and corrected for multiple comparisons with Tukey's honest significant difference using the pdmix800 macro in SAS.

\section{RESULTS}

Estimation of the incidence of infected stems and inoculum density of two isolates of $V$. dahliae from roots and soil of two brown mustards, white mustard, sweet corn, spring wheat, and sudangrass. Both isolates originally recovered from potato (653) and mint (111) were detected in stems of all dicotyledonous rotation crops, brown and white mustards, and isolate 111 was detected in stems of the monocotyledonous rotation crop, wheat (Fig. 1). Incidence of infected stems ranged from 0 to $100 \%$ and, among rotation crops, was greatest in brown mustard ISCI 199 and least in sweet corn and sudangrass. Significant differences in the incidence of infected stems were detected among crops (Table 2). Only differences between potato and rotation crops and among rotation crops are reported for the incidence of infected stems, root, and soil inoculum density data (Supplementary Table S1). The monocotyledonous crops were less $(P=0.02)$ than potato in the incidence of infected stems. Mustards were not different from potato and rotation crops were not different $(P \geq 0.06)$ from each other in the incidence of infected stems (Fig. 1).

Root infection was detected in all rotation crops (Fig. 1). Root inoculum density ranged from 0.1 to $40 \mathrm{CFU} / 60 \mathrm{~cm}$ of root. No significant differences in root inoculum density were detected among crops (Table 2). Soil inoculum density of isolates of V. dahliae ranged from 0.3 to $653 \mathrm{CFU} / \mathrm{g}$ of soil (Fig. 1). Significant differences in soil inoculum density were detected among crops (Table 2). Rotation crops were not different $(P>0.05)$ from potato in soil inoculum density. White mustard supported more $(P \leq 0.04)$ soil inoculum of isolate 111 than sweet corn and wheat (Fig. 1).

Estimation of inoculum density of eight isolates of $\mathrm{V}$. dahliae from stems, roots, and soil of arugula, Austrian winter pea, sweet corn, barley, and sudangrass. Typical Verticillium wilt 
symptoms were not observed in any of the rotation crops. A significant crop $\times$ isolate interaction $(F=2.5, P=0.0001)$ was detected in stem dry weight and warranted inspection of cell means. Austrian winter pea stem weight (g) decreased by 25 to $45 \%$ and was less $(P \leq 0.04)$ in plants grown in soil infested with isolates 653, 111, 461, VMD-4, and VD5 VSP699 than plants from noninfested soil. Sweet corn stem weight increased by 27 to $40 \%$ and was greater $(P \leq 0.03)$ in plants grown in soil infested with isolates 155, 461, VMD-4, and VD5 VSP699 than plants from noninfested soils. A significant crop $\times$ isolate interaction $(F=3.0$, $P=0.0001)$ was detected in root dry weight and warranted inspection of cell means. Arugula and sweet corn root weight (g) increased

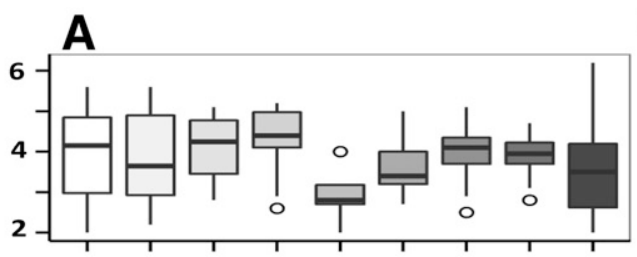

Potato

B

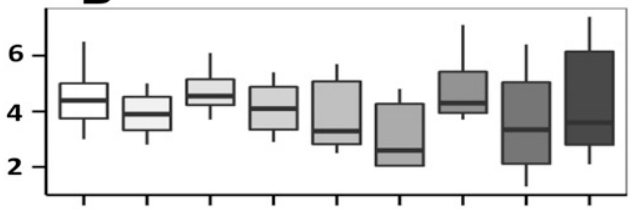

Peppermint
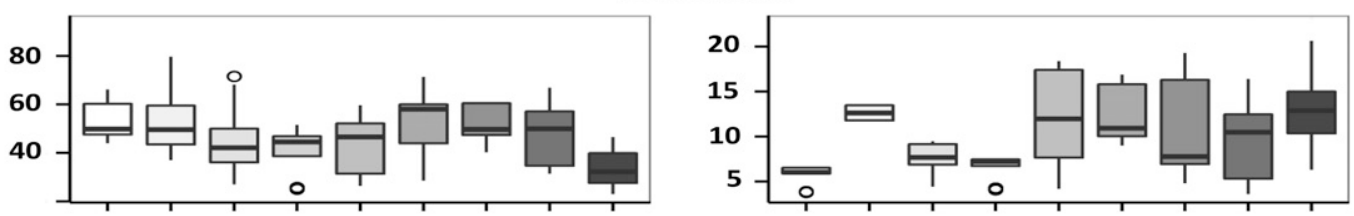

Arugula
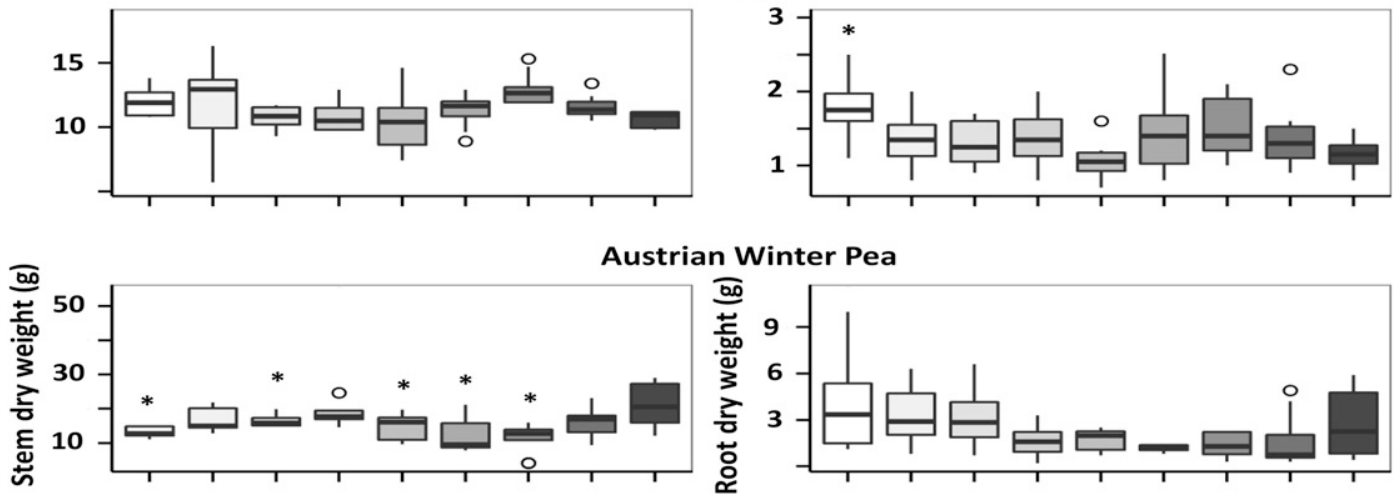

Sweet corn
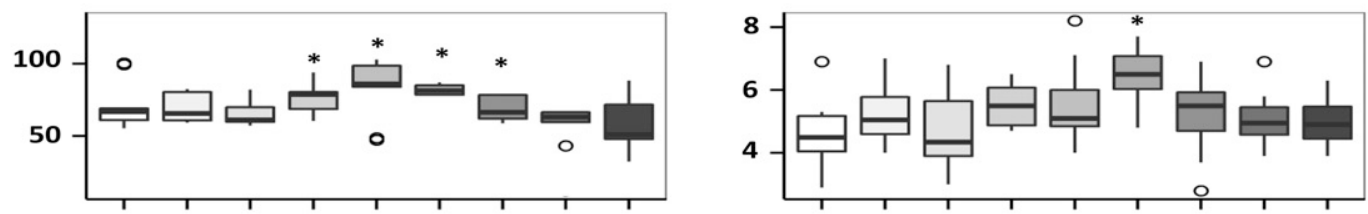

Barley
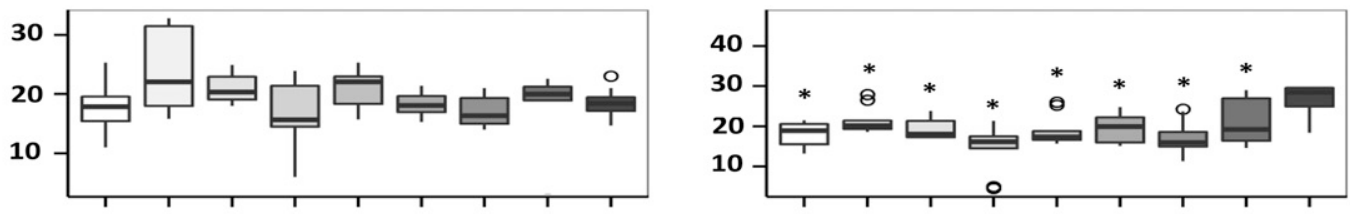

Sudangrass
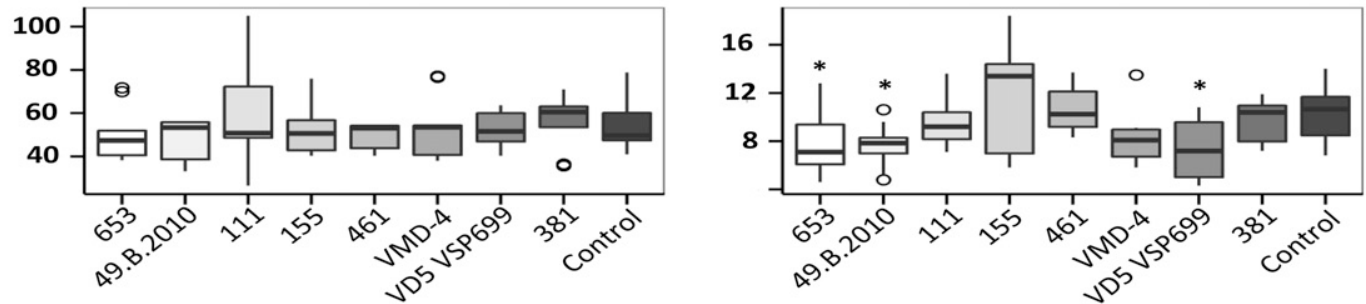

Fig. 2. Biomass of potato, peppermint, arugula, Austrian winter pea, sweet corn, barley, and sudangrass grown in soil infested with eight isolates of Verticillium dahliae and a noninfested control. A, Stem and B, root dry weight $(\mathrm{g})$ data are presented as boxplots. Boxplot hinges represent 1 st and 3rd quartiles, whiskers extend to values within $1.5 \times$ the interquartile range, and circles represent outliers. Nontransformed data are presented. Asterisks indicate significant differences $(P<0.05)$ between crops grown in infested soil and the noninfested controls. 
and was greater $(P \leq 0.004)$ in plants grown in soil infested with isolate 653 and isolate VMD-4 than plants from noninfested soils, respectively. Barley and sudangrass root weight decreased and was less $(P \leq 0.02)$ in plants grown in soil infested with all isolates and isolates 653, 49.B.2010, and VD5 VSP699 than plants from noninfested soils, respectively (Fig. 2).
At least one isolate of $V$. dahliae was detected from the stems of all rotation crops (Fig. 3). Isolates 653, 49.B.2010, 111, 155, VMD-4, and VD5 VSP699 were recovered from the dicotyledonous rotation crops, arugula, and Austrian winter pea, and one monocotyledonous rotation crop, barley. Isolates 461 and 381 exhibited wider host ranges than the other isolates and, in addition to the aforementioned
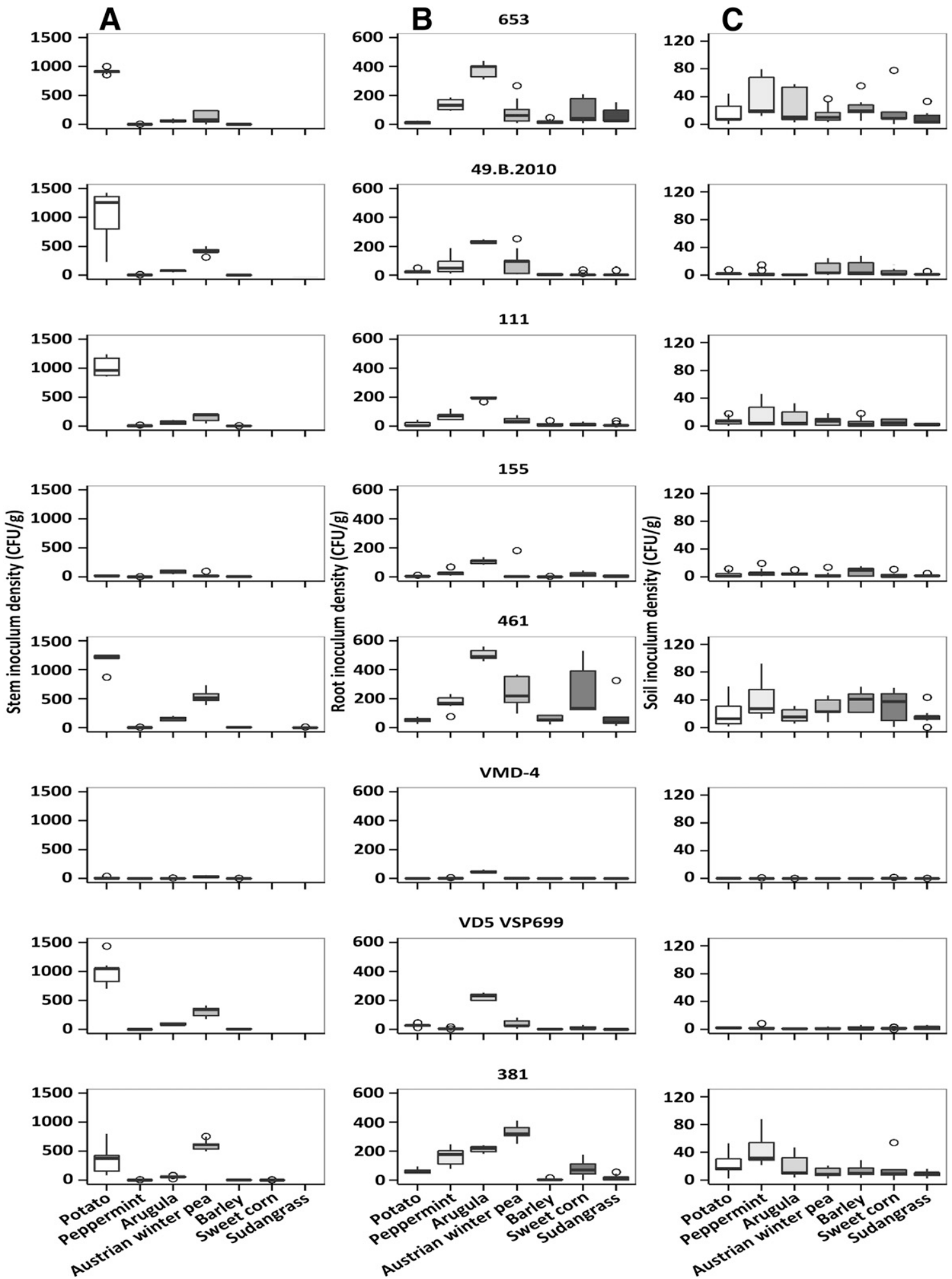

Fig. 3. Inoculum density of eight isolates Verticillium dahliae from stems, roots, and soil of arugula, Austrian winter pea, sweet corn, barley, and sudangrass. A, Stem inoculum density (CFU/g of stem), B, root inoculum density (CFU/g of root), and $\mathbf{C}$, soil inoculum density (CFU/g of soil) detected from crops grown in soil infested with eight isolates of $V$. dahliae are presented as boxplots. Boxplot hinges represent 1 st and 3 rd quartiles, whiskers extend to values within $1.5 \times$ the interquartile range, and circles represent outliers. 
rotation crops, were recovered from sudangrass or sweet corn, respectively. Inoculum density of $V$. dahliae ranged from 0 to 1436 $\mathrm{CFU} / \mathrm{g}$ of stem and, among rotation crops, was greatest in Austrian winter pea infected with isolate 381 . Microsclerotia were observed in stems of all infected rotation crops.

Significant differences in stem inoculum density were detected among crops and a crop $\times$ isolate interaction warranted inspection of cell means (Table 3 ). Only differences between potato and rotation crops and among rotation crops are reported for stem, root, and soil inoculum density data (Supplementary Table S2). The crop effect explained more variability in the model $\left(R^{2}=0.32\right)$ than the isolate

TABLE 3. Permutational multivariate analysis of variance (PERMANOVA) tables for stem, root, and soil inoculum density of eight isolates of Verticillium dahliae estimated from arugula, Austrian winter pea, sweet corn, barley, and sudangrass, potato, and peppermint

\begin{tabular}{lrrrr}
\hline Source of variation & df & Sum of squares & Pseudo- $F$ & $P($ perm $)$ \\
\hline Stem inoculum density & & & & \\
$\quad$ Crop & 6 & $377,720.00$ & $2,782.70$ & 0.0002 \\
Isolate & 7 & $35,054.00$ & 957.18 & 0.0001 \\
Block & 4 & 135.84 & 0.33 & 0.9078 \\
Trial & 1 & 34.17 & 0.33 & 0.6262 \\
Crop $\times$ isolate & 42 & $49,792.00$ & 159.07 & 0.0001 \\
Crop $\times$ trial & 6 & 435.74 & 0.52 & 0.5883 \\
Isolate $\times$ trial & 7 & 636.62 & 0.85 & 0.3689 \\
Crop $\times$ isolate $\times$ trial & 42 & 513.01 & 0.73 & 0.4783 \\
Root inoculum density & & & & \\
Crop & 6 & $77,239.00$ & 47.45 & 0.0003 \\
Isolate & 7 & $102,190.00$ & 53.25 & 0.0001 \\
Block & 4 & $5,777.40$ & 11.85 & 0.0001 \\
Trial & 1 & 56.50 & 0.72 & 0.4020 \\
Crop $\times$ isolate & 42 & $36,204.00$ & 6.81 & 0.0001 \\
Crop $\times$ trial & 6 & 627.50 & 0.82 & 0.3862 \\
Isolate $\times$ trial & 7 & 719.10 & 0.94 & 0.1840 \\
Crop $\times$ isolate $\times$ trial & 42 & $5,310.80$ & 1.03 & 0.4024 \\
Soil inoculum density & & & & \\
Crop & 6 & $2,646.80$ & 21.00 & 0.0001 \\
Isolate & 7 & $100,710.00$ & 670.72 & 0.0001 \\
Block & 4 & 539.21 & 0.81 & 0.5335 \\
Trial & 1 & 110.60 & 0.67 & 0.4495 \\
Crop $\times$ isolate & 42 & $11,246.00$ & 19.31 & 0.0001 \\
Crop $\times$ trial & 6 & 326.02 & 0.32 & 0.7943 \\
Isolate $\times$ trial & 7 & 550.16 & 0.63 & 0.3217 \\
Crop $\times$ isolate $\times$ trial & 42 & 782.32 & 0.84 & 0.2148 \\
\hline & & & & \\
\hline
\end{tabular}

effect $\left(R^{2}=0.20\right)$ or the crop $\times$ isolate interaction $\left(R^{2}=0.17\right)$. Dicotyledonous rotation crops, arugula and Austrian winter pea were greater $(P \leq 0.04)$ than potato in stem inoculum density of isolate 155 and isolates VMD-4 and 381, respectively (Fig. 3). Austrian winter pea and potato did not differ $(P=0.07)$ in stem inoculum density of isolate 155 . Monocotyledonous rotation crops, sweet corn, barley, and sudangrass were less $(P \leq 0.05)$ than potato in stem inoculum density of all isolates (Fig. 3).

Rotation crops varied in the incidence of infected stems and inoculum density. The monocotyledonous crops were less $(P \leq 0.04)$ than arugula and Austrian winter pea in stem inoculum density of isolates 49.B.2010, 111, 155, 461, VMD-4, VD5 VSP699, and 381 (Fig. 3). Sweet corn and sudangrass were less $(P \leq 0.02)$ than barley in stem inoculum density of isolates 653, 49.B.2010, 111, 155, 461, VD5 VSP699, and 381.

Isolates 49.B.2010 and 381 were detected in seed of arugula and isolates 653, 49.B.2010, 461, VMD-4, and 381 were detected in seed of Austrian winter pea. Incidence of contaminated seed ranged from 0 to $0.4 \%$ in arugula and from 0 to $7 \%$ in Austrian winter pea (data not shown).

Root infection was detected on all rotation crops (Fig. 3). Root inoculum density of $V$. dahliae ranged from 0.1 to $560 \mathrm{CFU} / \mathrm{g}$ of root. Significant differences in root inoculum density were detected among crops and a crop $\times$ isolate interaction warranted inspection of cell means (Table 3$)$. Arugula was greater $(P \leq 0.03)$ than potato in root inoculum density of isolates 653, 49.B.2010, 111, 461, VMD-4, VD5 VSP699, and 381 (Fig. 3). Austrian winter pea was greater $(P \leq 0.02)$ than potato in root inoculum density of isolates 653,461 , and 381. Sweet corn and sudangrass were greater $(P \leq 0.03)$ than potato in root inoculum density of isolates 653 and 461 and isolate 653, respectively (Fig. 3).

Soil inoculum density of isolates of $V$. dahliae ranged from 0.03 to $88 \mathrm{CFU} / \mathrm{g}$ of soil (Fig. 3). Significant differences in soil inoculum density were detected among crops and a crop $\times$ isolate interaction warranted inspection of cell means (Table 3). Austrian winter pea and barley were greater $(P \leq 0.04)$ than potato in soil inoculum density of isolate 461 . Rotation crops did not differ $(P \geq 0.08)$ from potato in soil inoculum density of isolates 49.B.2010, VMD-4, and 381 (Fig. 3).

Axis 1 of the NMDS biplot (Fig. 4) separated crops that supported more inoculum density (left) from crops that supported less

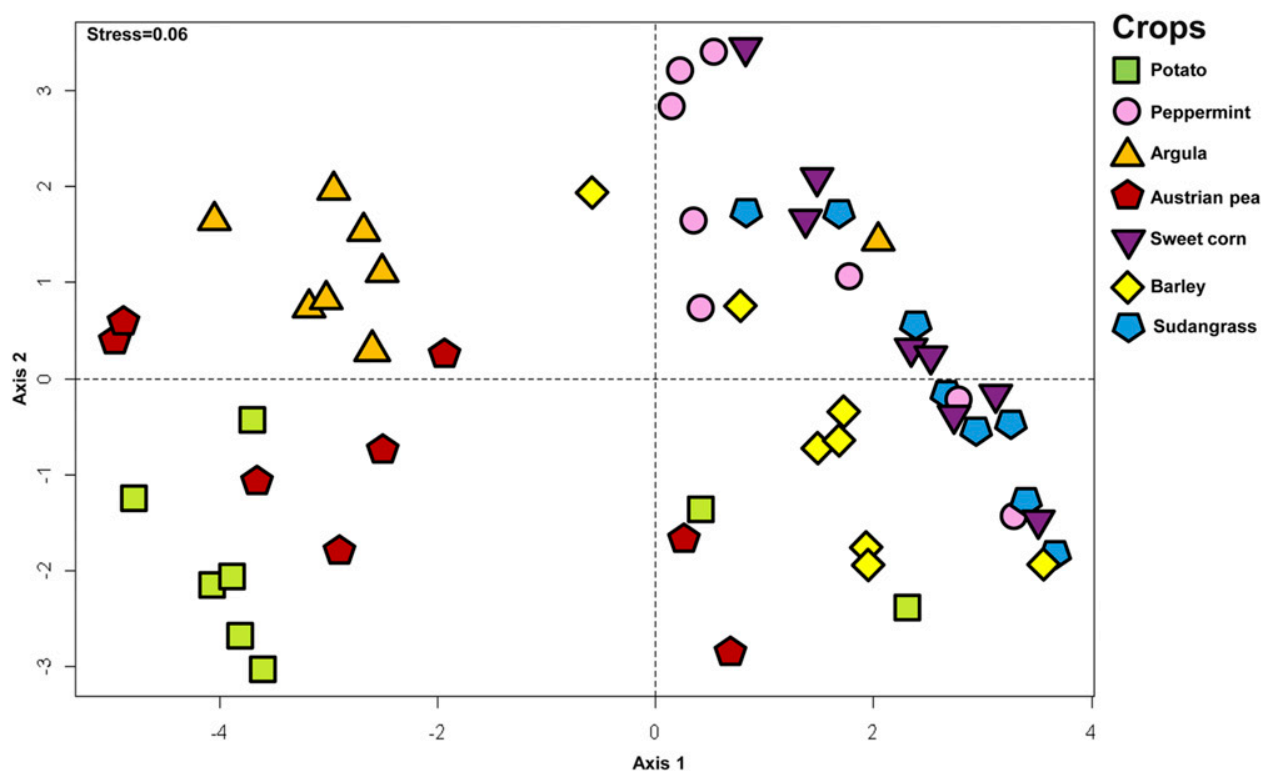

Fig. 4. Similarity of inoculum density among crops infected with isolates of Verticillium dahliae plotted with nonmetric multidimensional scaling using the BrayCurtis similarity matrix. Points represent the total inoculum density detected from stems, roots and soil of crops. Crops are depicted with different shapes and colors and the eight isolates are represented by the eight points within each crop. 
inoculum (right) independent of expression of wilt symptoms. For example, potato, which expressed wilt symptoms, and arugula and Austrian winter pea, which did not express wilt symptoms, supported more inoculum, and clustered together, whereas peppermint, which expressed wilt symptoms, and the grasses, which did not express wilt symptoms, supported less inoculum and clustered together.

Detection of Verticillium spp. in commercial fields. Incidence of fields with rotation crops infected by Verticillium spp. was 8 of 21 (38\%) (Table 4). Incidence of stems infected with Verticillium spp. within each field ranged from 1 to $63 \%$. Incidence of infected stems was greatest in brown mustard from one field. No typical wilt symptoms were observed on rotation crops collected from commercial fields. Microsclerotia of Verticillium spp. were observed with microscopy on stems of both brown mustard cultivars but not on other rotation crops (data not shown).

Identification of isolates collected from rotation crops in fields with a history of Verticillium wilt. Fungal isolates were identified as $V$. dahliae based on erect, hyaline, verticillately arranged phialidic conidiophores, hyaline cylindrical conidia, multicellular melanized microsclerotia, and the absence of yellow pigmentation. V. isaacii was tentatively identified as above; however, these isolates produced resting mycelia as well as microsclerotia and yellow pigment. Furthermore, isolates were identified as $V$. dahliae, or $V$. isaacii in the case of the isolates collected from sunflower, based on BLAST queries of sequence data from EF1- $a, G P D, A C T$, and $T S$ against reference isolates from Inderbitzin et al. (2011a, b). Specifically, $V$. dahliae sequence data from EF1- $a$ were queried against accessions HQ414625 and HQ414648 and V. isaacii data were queried against HQ414688 and JN188237; V. dahliae sequence data from ACT were queried against HQ206922 and HQ206984 and $V$. isaacii data were queried against HQ206985 and JN188092; $V$. dahliae sequence data from $G P D$ were queried against HQ414720 and HQ414743 and V. isaacii data were queried against HQ414783 and JN188173; and V. dahliae sequence data from $T S$ were queried against HQ414972 and HQ414914 and V. isaacii data were queried against HQ414973 and JN188045. Sequence data from each isolate were deposited on GenBank and are presented in Table 4. GenBank accession numbers are
KT224535 to KT224553 for EF1- $a$, KT224554 to KT224572 for $G P D, \mathrm{KT} 224573$ to KT224591 for ACT, and KT224760 to KT224778 for $T S$.

\section{DISCUSSION}

Crop rotations that minimize the development and persistence of $V$. dahliae inoculum in potato production systems are needed to supplement or replace existing management tactics. However, the impacts of crop rotation on Verticillium wilt and inoculum density of $V$. dahliae are inconsistent (Davis et al. 1994; Huisman and Ashworth 1976; Joaquim et al. 1988; Johnson and Cummings 2015; Larkin et al. 2011; O'Sullivan 1978; Subbarao et al. 2007; Wheeler et al. 2012). Sources of the inconsistent results include the spatial and temporal heterogeneity of $V$. dahliae populations among and within fields (Joaquim et al. 1988; Powelson and Rowe 1993), the crops planted in rotations (Green 1969), and the lengths of rotation (Gudmestad et al. 2007; Powelson and Rowe 1993). Observed inconsistencies may also be due, in part, to differential infection by and inoculum production on crops planted in rotation with primary crops. The identification of rotation crops that minimize or reduce $V$. dahliae soil inoculum is therefore of paramount importance when designing crop rotation regimes.

This study provides evidence that the infection of numerous rotation crops by $V$. dahliae has the potential to increase inoculum levels of the organism and potentially increase losses in potato and mint cropping systems in the Pacific Northwest of the United States. The expanded host range, differential inoculum production, and responses in plant biomass to infection supports a diverse life history of $V$. dahliae whereby isolates can infect and incite typical symptoms in primary hosts, alter biomass, or incite no symptoms in other hosts. Before recommendations can be made additional questions need to be addressed: do microsclerotia produced on rotation crops survive and contribute to soil inoculum to the same extent as microsclerotia produced on primary crops; what crop rotation sequences minimize the potential contribution of microsclerotia to soil inoculum; are infections of rotation crops stable or will new Verticillium wilts emerge over time; are rotation crops of potato and mint infected by $V$. dahliae worldwide or regionally; and

TABLE 4. Incidence of infected stems of rotation crops and Genbank accessions of actin (ACT), elongation factor 1 alpha (EF1-a), glyceraldehyde-3-phosphate $(G P D)$, and tryptophan synthase $(T S)$ sequences from Verticillium dahliae isolates collected from 21 fields with a history of Verticillium wilt of potato or mint in the Columbia Basin, Washington

\begin{tabular}{|c|c|c|c|c|c|c|c|}
\hline $\begin{array}{l}\text { Rotation crops } \\
\text { sampled }\end{array}$ & $n$ & $\begin{array}{l}\text { Incidence } \\
(\%)\end{array}$ & $A C T$ & $E F 1-a$ & $G P D$ & $T S$ & Species \\
\hline Arugula 'Nemat' & 50 & 0 & $\ldots$ & $\ldots$ & $\ldots$ & $\ldots$ & $\ldots$ \\
\hline Arugula 'Nemat' & 50 & 0 & $\ldots$ & $\ldots$ & $\ldots$ & $\ldots$ & $\ldots$ \\
\hline Brown mustard ${ }^{\mathrm{a}}$ & 150 & 63 & КT224573, КТ224574 & КT224535, КТ224536 & KT224554, КT224555 & КT224760, КT224761 & V. dahliae \\
\hline Millet & 50 & 2 & КT224575, КТ224576 & KT224537, КT224538 & KT224556, КT224557 & КT224762, KT224763 & V. dahliae \\
\hline Brown mustard ${ }^{a}$ & 50 & 14 & KT224577, КТ224578 & КT224539, КТ224540 & КT224558, КT224559 & KT224764, KT224765 & V. dahliae \\
\hline Wheat & 50 & 2 & КT224579, КТ224580 & KT224541, КT224542 & KT224560, KT224561 & KT224766, КT224767 & V. dahliae \\
\hline \multicolumn{8}{|l|}{ White mustard } \\
\hline 'Martigena' & 50 & 6 & KT224581, KT224582 & KT224543, КT224544 & KT224562, KT224563 & КT224768, КT224769 & V. dahliae \\
\hline Sunflower & 25 & 24 & KT224585, КT224586 & KT224547, КT224548 & КT224566, КТ224567 & KT224772, KT224773 & V. isaacii \\
\hline Pea & 100 & 0 & $\ldots$ & $\ldots$ & $\ldots$ & $\ldots$ & $\ldots$ \\
\hline Pea & 100 & 0 & $\ldots$ & $\ldots$ & $\ldots$ & $\ldots$ & $\ldots$ \\
\hline Bean & 100 & 0 & $\ldots$ & $\ldots$ & $\ldots$ & $\ldots$ & $\ldots$ \\
\hline Buckwheat & 100 & 7 & КT224587, КТ224588 & КТ224549, КТ224550 & KT224568, КT224569 & КT224774, КT224775 & V. dahliae \\
\hline Buckwheat & 100 & 9 & КT224589, КТ224590 & KT224551, KT224552 & KT224570, KT224571 & KT224776, КT224777 & V. dahliae \\
\hline Buckwheat & 100 & 0 & $\ldots$ & $\ldots$ & $\ldots$ & $\ldots$ & $\ldots$ \\
\hline Dill & 100 & 0 & $\ldots$ & $\ldots$ & $\ldots$ & $\ldots$ & $\ldots$ \\
\hline Corn & 100 & 1 & KT224584 & KT224546 & KT224565 & KT224771 & V. dahliae \\
\hline Corn & 100 & 0 & $\ldots$ & $\ldots$ & $\ldots$ & $\ldots$ & $\ldots$ \\
\hline Corn & 100 & 0 & $\ldots$ & $\ldots$ & $\ldots$ & $\ldots$ & $\ldots$ \\
\hline Corn & 100 & 0 & $\ldots$ & $\ldots$ & $\ldots$ & $\ldots$ & $\ldots$ \\
\hline Oat & 100 & 0 & $\ldots$ & $\ldots$ & $\ldots$ & $\ldots$ & $\ldots$ \\
\hline Oat & 100 & 0 & $\ldots$ & $\ldots$ & $\ldots$ & $\ldots$ & $\ldots$ \\
\hline Barley & 100 & 10 & KT224583, КT224591 & KT224545, КT224553 & KT224564, KT224572 & KT224770, КT224778 & V. dahliae \\
\hline Timothy & 100 & 0 & $\ldots$ & $\ldots$ & $\ldots$ & $\ldots$ & $\ldots$ \\
\hline
\end{tabular}

${ }^{a}$ Millet was intercropped with brown mustard in one field and wheat was intercropped with brown mustard in a separate field. 
are isolates of $V$. dahliae recovered from rotation crops pathogenic to potato and peppermint?

Rotation crops of potato and mint were infected by $V$. dahliae in controlled greenhouse experiments and in commercial fields in Washington State. The incidence of infected stems was relatively low in most commercial fields sampled and may be explained by the rare occurrence of asymptomatic infections under field conditions and or the use of a culture dependent detection method biased toward vigorously growing isolates. The former explanation is supported by the low incidence of infected stems detected in published studies (Demirci and Genc 2009; Krikun and Bernier 1987; Malcolm et al. 2013). To understand the potential role of infected rotation crops in Verticillium wilt epidemiology the geographical distribution of infected rotation crops should continue to be investigated in regions where crops susceptible to $V$. dahliae are grown.

Detection of microsclerotia from at least one isolate of $V$. dahliae on each rotation crop in this study has expanded the known host range of the organism. This is the first experimental documentation of stem infection of brown mustard, white mustard, arugula, Austrian winter pea, sweet corn, and sudangrass by V. dahliae according to the United States Department of Agriculture Systematic Mycology and Microbiology Fungus-Host database (http://nt.ars-grin.gov/fungaldatabases/fungushost/fungushost.cfm). Detection of $V$. dahliae from stems of wheat and barley corroborates previous reports (Krikun and Bernier 1987; Mathre 1986). The expansion of the known host range of $V$. dahliae is of particular importance for mustards, sweet corn, and sudangrass, which are often grown as green manures (Davis et al. 2010a; Larkin and Halloran 2014) and may be efficacious in disease-suppression if plant biomass is incorporated into soils before microsclerotia form on senescing plant tissues.

The presence of different host ranges among some of the isolates used in this experiment supports the existence of host specificity in $V$. dahliae. All isolates colonized a subset of rotation crop stems and were therefore host specific; however, isolates 461 and 381 exhibited wider host ranges than the other isolates included. These observations corroborate previous reports of host specificity (Bhat and Subbarao 1999; Krikun and Bernier 1987) and may help explain the reported variability in the effectiveness of crop rotation for managing Verticillium wilt (cited above). Hence, rotations with the monocotyledonous rotation crops not included in the host range of some isolates used here may be more effective in minimizing potential inoculum production and or the incidence of Verticillium wilt in primary crops than the dicotyledonous crops evaluated (Davis et al. 1996, 1998; Larkin et al. 2010).

The presence of significant crop $\times$ isolate interactions for stem inoculum density and plant biomass support the existence of host-adapted isolates of $V$. dahliae whereby differences in stem inoculum density and plant biomass depend on the isolate with which each crop was infected. Isolates 155 and 381, for example, were host-adapted and produced more inoculum on arugula or Austrian winter pea than potato, respectively. Evidence of hostadapted isolates of $V$. dahliae corroborates previous reports from potato and cotton pathosystems (Douhan and Johnson 2001; Korolev et al. 2008; Rowe and Powelson 2002). The observed differences among host-specific and host-adapted isolates may be explained by (i) differences in V. dahliae fitness, (ii) the host from which the isolate was recovered (Alkher et al. 2009; Fordyce and Green 1960), (iii) differences in the ability of hosts to induce germination of microsclerotia (Mol and van Riessen 1995) and resist infection or the development of microsclerotia (Krikun and Bernier 1987; Slattery 1981), and or (iv) differences in host microbiomes (Berendsen et al. 2012). The effectiveness of crop rotation for managing Verticillium wilt will therefore be contingent upon the pathogenicity of populations of V. dahliae present in fields, the crop planted in rotation with the primary crop, the potential contribution of inoculum formed on the rotation crops, and environmental conditions.
A range of responses in plant biomass to infection of rotation crops also supports the existence of host-adapted isolates and putative nonpathogenic interactions between $V$. dahliae and some hosts. While stem weight of most rotation crops was not altered by infection, stem weight of Austrian winter pea decreased while stem weight of sweet corn increased when infected by some, but not all, isolates of $V$. dahliae. Mild to typical wilt symptoms were observed in potato plants grown in infested soils but these symptoms did not uniformly decrease biomass and were not reported herein. The asymptomatic infections reported here corroborate those reviewed by Malcolm et al. (2013). The symptomatic infections are similar but not identical to the alterations in the growth and development observed by Robb et al. (2007) and Veronese et al. (2003) where some infected hosts were taller or flowered earlier or later and produced more stems than noninfected controls; however, unlike results presented here, these changes in plant growth were accompanied by mild (Robb et al. 2007) and typical (Veronese et al. 2003) symptom expression.

Characterization of the herein reported asymptomatic and symptomatic infections of rotation crops is essential to determine the sustainability of crop rotation on potato and mint cropping systems. Assignment of asymptomatic and symptomatic infections within the symbiotic continuum may be completed by a combination of serial passage experiments (Ebert 1998; Fordyce and Green 1960; Little et al. 2006) and descriptions of changes in plant growth, plant development, rates of metabolism, and tolerance to stress in response to infection (Rodriguez and Roossinck 2012). This approach may be used to test the stability of infections over time, predict the emergence of aggressive isolates, and help inform growers when designing rotation crop regimes.

\section{ACKNOWLEDGMENTS}

We acknowledge the Northwest Potato Research Consortium and Mint Industry Research Council for providing financial support for this research. PPNS number 0693, Department of Plant Pathology, College of Agricultural, Human, and Natural Resource Sciences, Agricultural Research Center, Hatch Project Number WNP00678, Washington State University, Pullman, WA 99164-6430.

\section{LITERATURE CITED}

Alkher, H., El Hadrami, A., Rashid, K. Y., Adam, L. R., and Daayf, F. 2009. Pathogenic variation of Verticillium dahliae after serial passages through potato and sunflower. Can. J. Plant Pathol. 31:427-438.

Altschul, S. F., Madden, T. L., Schäffer, A. A., Zhang, J., Zhang, Z., Miller, W., and Lipman, D. J. 1997. Gapped BLAST and PSI-BLAST: A new generation of protein database search programs. Nucleic Acids Res. 25: 3389-3402.

Anderson, M. J. 2001. A new method for non-parametric multivariate analysis of variance. Austral Ecol. 26:32-46.

Anderson, M. J., Gorely, R. N., and Clarke, K. R. 2008. PERMANOVA+ for PRIMER: Guide to software and statistical methods. PRIMER-E, Plymouth, UK.

Benjamini, Y., and Hochberg, Y. 1995. Controlling the false discovery rate: A practical and powerful approach to multiple testing. J. R. Stat. Soc. Ser. B. Stat. Methodol. 57:289-300.

Benson, D. M., and Ashworth, L. J., Jr. 1976. Survival of Verticillium alboatrum on nonsuscept roots and residues in field soils. Phytopathology 66: 883-887.

Berendsen, R. L., Pieterse, C. M. J., and Bakker, P. A. H. M. 2012. The rhizosphere microbiome and plant health. Trends Plant Sci. 17:478-486.

Bhat, R. G., and Subbarao, K. V. 1999. Host range specificity in Verticillium dahliae. Phytopathology 89:1218-1225.

Bolker, B. M., Brooks, M. E., Clark, C. J., Geange, S. W., Poulsen, J. R., Stevens, M. H. H., and White, J.-S. S. 2009. Generalized linear mixed models: A practical guide for ecology and evolution. Trends Ecol. Evol. 24: 127-135.

Buckley, P. M., Wyllie, T. D., and DeVay, J. E. 1969. Fine structure of conidia and conidium formation in Verticillium albo-atrum and V. nigrescens. Mycologia 61:240-250.

Butterfield, E. J., and DeVay, J. E. 1977. Reassessment of soil assays for Verticillium dahliae. Phytopathology 67:1073-1078. 
Butterfield, E. J., DeVay, J. E., and Garber, R. H. 1978. The influence of several crop sequences on the incidence of Verticillium wilt of cotton and on the populations of Verticillium dahliae in field soil. Phytopathology 68: 1217-1220.

Clarke, K. R. 1993. Non-parametric multivariate analyses of changes in community structure. Aust. J. Ecol. 18:117-143.

Clarke, K. R., Somerfield, P. J., and Chapman, M. G. 2006. On resemblance measures for ecological studies, including taxonomic dissimilarities and a zero-adjusted Bray-Curtis coefficient denuded assemblages. J. Exp. Mar. Biol. Ecol. 330:55-80.

Cochran, W. G. 1977. Stratified random sampling. Pages 89-110 in: Sampling Techniques, 3rd ed. Wiley, New York.

Davis, J. R., Huisman, O. C., Everson, D. O., Nolte, P., Sorensen, L. H., and Schneider, A. T. 2010a. The suppression of Verticillium wilt of potato using corn as a green manure crop. Am. J. Potato Res. 87:195-208.

Davis, J. R., Huisman, O. C., Everson, D. O., Nolte, P., Sorensen, L. H., and Schneider, A. T. 2010b. Ecological relationships of Verticillium wilt suppression of potato by green manures. Am. J. Potato Res. 87:315-326.

Davis, J. R., Huisman, O. C., Everson, D. O., Schneider, A. T., and Sorensen, L. H. 1998. Suppression of Verticillium wilt with wheat and improved yield and quality of the Russet Burbank potato. Am. J. Potato Res. 82:64.

Davis, J. R., Huisman, O. C., Westermann, D. T., Hafez, S. L., Everson, D. O., Soreson, L. H., and Schneider, A. T. 1996. Effects of green manures on Verticillium wilt of potato. Phytopathology 86:444-453.

Davis, J. R., Pavek, J. J., Corsini, D. L., Sorensen, L. H., Schneider, A. T., Everson, D. O., Westermann, D. T., and Huisman, O. C. 1994. Influence of continuous cropping of several potato clones on the epidemiology of Verticillium wilt of potato. Phytopathology 84:207-214.

Demirci, E., and Genc, T. 2009. Vegetative compatibility groups of Verticillium dahliae isolates from weeds in potato fields. J. Plant Pathol. 91: 671-676.

Dobinson, K. F. 1995. Genetic transformation of the vascular wilt pathogen Verticillium dahliae. Can. J. Bot. 73:710-715.

Douhan, L. I., and Johnson, D. A. 2001. Vegetative compatibility and pathogenicity of Verticillium dahliae from spearmint and peppermint. Plant Dis. 85:297-302.

Dung, J. K. S., Peever, T. L., and Johnson, D. A. 2013. Verticillium dahliae populations from mint and potato are genetically divergent with predominant haplotypes. Phytopathology 103:445-459.

Dung, J. K. S., Schroeder, B. K., and Johnson, D. A. 2010. Evaluation of Verticillium wilt resistance in Mentha arvensis and M. longifolia genotypes. Plant Dis. 94:1255-1260.

Easton, G. D., Nagle, M. E., and Seymour, M. D. 1992. Potato production and incidence of Verticillium dahliae following rotation to nonhost crops and soil fumigation in the state of Washington. Am. J. Potato Res. 69:489-502.

Ebert, D. 1998. Experimental evolution of parasites. Science 282:1432-1436.

Emmaty, D. A., and Green, R. J., Jr. 1969. Fungistasis and the behavior of the microsclerotia of Verticillium albo-atrum in soil. Phytopathology 59: 1590-1595.

Evans, G., and Gleeson, A. C. 1973. Observations on the origin and nature of Verticillium dahliae colonizing plant roots. Aust. J. Biol. Sci. 26:151-161.

Eynck, C., Koopmann, B., Grunwaldt-Stoecker, G., Karlovsky, P., and von Tiedmann, A. 2007. Differential interactions of Verticillium longisporum and $V$. dahliae with Brassica napus detected with molecular and histological techniques. Eur. J. Plant Pathol. 118:259-274.

Fordyce, C., and Green, K. J. 1960. Studies of host specificity of Verticillium albo-atrum var. menthae. Phytopathology 50:635.

Galanopoulos, N., and Tribe, H. T. 1974. Conidial survival in Verticillium dahliae. Trans. Br. Mycol. Soc. 63:85-91.

Glickman, M. E., Roa, S. R., and Schultz, M. R. 2014. False discovery rate control is a recommended alternative to Bonferroni-type adjustments in health studies. J. Clin. Epidemiol. 67:850-857.

Goud, J. C., and Termorshuizen, A. J. 2003. Quality of methods to quantify microsclerotia of Verticillium dahliae in soil. Eur. J. Plant Pathol. 109:523-534.

Green, R. J. 1969. Survival and inoculum potential of conidia and microsclerotia of Verticillium albo-atrum in soil. Phytopathology 59:874-876.

Gudmestad, N. C., Taylor, R. J., and Pasche, J. S. 2007. Management of soilborne disease of potato. Australas. Plant Pathol. 46:109-115.

Horner, C. E. 1954. Pathogenicity of Verticillium isolates to peppermint. Phytopathology 44:239-242.

Huisman, O. C., and Ashworth, L. J. 1976. Influence of crop rotation on survival of Verticillium albo-atrum in soils. Phytopathology 66:978-981.

Inderbitzin, P., Bostock, R. M., Davis, M. R., Usami, T., Platt, H. W., and Subbarao, K. V. 2011a. Phylogenetics and taxonomy of the fungal vascular wilt pathogen Verticillium, with the descriptions of five new species. PLoS One 6:e28341.

Inderbitzin, P., Davis, R. M., Bostock, R. M., and Subbarao, K. V. 2011b. The ascomycete Verticillium longisporum is a hybrid and a plant pathogen with an expanded host range. PLoS One 6:e18260.
Isaac, I., and Harrison, J. A. 1968. The symptoms and causal agents of early dying disease (Verticillium wilt) of potatoes. Ann. Appl. Biol. 61:231-244.

Joaquim, T. R., Smith, V. L., and Rowe, R. C. 1988. Seasonal variation and effects of wheat rotation on populations of Verticillium dahliae Kleb. in Ohio potato field soils. Am. J. Potato Res. 65:439-447.

Johnson, D. A., and Cummings, T. F. 2015. Effect of extended crop rotations on incidence of black dot, silver scurf, and Verticillium wilt of potato. Plant Dis. 99:257-262.

Johnson, D. A., and Dung, J. K. S. 2010. Verticillium wilt of potato-The pathogen, disease and management. Can. J. Plant Pathol. 32:58-67.

Kabir, Z., Bhat, R. G., and Subbarao, K. V. 2004. Comparison of media for recovery of Verticillium dahliae from soil. Plant Dis. 88:49-55.

Klosterman, S. J., Atallah, Z. K., Vallad, G. E., and Subbarao, K. V. 2009. Diversity, pathogenicity and management of Verticillium species. Annu. Rev. Phytopathol. 47:39-62.

Korolev, N., Pérez-Artés, E., Mercado-Blanco, J., Bejarano-Alcázar, J., Rodríguez-Jurado, D., Jiménez-Díaz, R. M., Katan, T., and Katan, J. 2008. Vegetative compatibility of cotton-defoliating Verticillium dahliae in Israel and its pathogenicity to various crop plants. Eur. J. Plant Pathol. 122:603-617.

Krikun, J., and Bernier, C. C. 1987. Infection of several crops species by two isolates of Verticillium dahliae. Can. J. Plant Pathol. 9:241-245.

Kruskal, J. B. 1964. Multidimensional scaling by optimizing goodness of fit to a nonmetric hypothesis. Psychometrika 29:1-27.

Lacy, M. L., and Horner, C. E. 1966. Behavior of Verticillium dahliae in the rhizosphere and on the roots of plants susceptible, resistant and immune to wilt. Phytopathology 56:427-430.

Larkin, R. P., Griffin, T. S., and Honeycutt, C. W. 2010. Rotation and cover crop effects on soilborne potato diseases, tuber yield, and soil microbial communities. Plant Dis. 94:1491-1502.

Larkin, R. P., and Halloran, J. M. 2014. Management effects of diseasesuppressive rotation crops on potato yield and soilborne disease and their economic implications in potato production. Am. J. Potato Res. 91:429-439.

Larkin, R. P., Honeycutt, C. W., and Olanya, O. M. 2011. Management of Verticillium wilt of potato with disease-suppressive green manures and as affected by previous cropping history. Plant Dis. 95:568-576.

Legendre, P., and Legendre, L. 1998. Nonmetric multidimensional scaling. Pages 444-451 in: Numerical Ecology, 2nd ed. Elsevier, Amsterdam.

Little, T. J., Watt, K., and Ebert, D. 2006. Parasite-host specificity: Experimental studies on the basis of parasite adaptation. Evolution 60:31-38.

MacGuidwin, A. E., Knuteson, D. L., Connell, T., Bland, W. L., and Bartelt, K. D. 2012. Manipulating inoculum densities of Verticillium dahliae and Pratylenchus penetrans with green manure amendments and solarization influence potato yields. Phytopathology 102:519-527.

Malcolm, G. M., Kuldau, G. A., Gugino, B. K., and Jiménez-Gasco, M. M. 2013. Hidden host plant associations of soilborne fungal pathogens: An ecological perspective. Phytopathology 103:538-544.

Malik, N. K., and Milton, J. M. 1980. Survival of Verticillium in monocotyledonous host plants. Trans. Br. Mycol. Soc. 75:496-498.

Martison, C. A., and Horner, C. E. 1962. Importance of non-hosts in maintaining inoculum potential of Verticillium. Phytopathology 52:742.

Mathre, D. E. 1986. Occurrence of Verticillium dahliae on barley. Plant Dis. 70:981.

McCune, B., and Grace, J. B. 2002. Nonmetric multidimensional scaling. Pages 102-142 in: Analysis of Ecological Communities. MjM Software Design, Gleneden Beach, OR.

Mol, L. 1995a. Effect of plant roots on the germination of microsclerotia of Verticillium dahliae II. Quantitative analysis of the luring effect of crops. Eur. J. Plant Pathol. 101:679-685.

Mol, L. 1995b. Formation of microsclerotia of Verticillium dahliae on various crops. Neth. J. Agric. Sci. 43:205-215.

Mol, L., and Scholte, K. 1995. Formation of microsclerotia of Verticillium dahliae Kleb. on various plant parts of two potato cultivars. Potato Res. 38: 143-150.

Mol, L., Scholte, K., and Vos, J. 1995. Effects of crop rotation and removal of crop debris on the soil population of two isolates of Verticillium dahliae. Plant Pathol. 44:1070-1074

Mol, L., and van Riessen, H. W. 1995. Effect of plant roots on the germination of microsclerotia of Verticillium dahliae. 1. Use of root observation boxes to asses differences among crops. Eur. J. Plant Pathol. 101:673-678.

National Agricultural Statistics Service. 2015. Crop production. United States Department of Agriculture, Washington, D.C.

Njoroge, S. M. C., Kabir, Z., Martin, F. N., Koike, S. T., and Subbarao, K. V. 2009. Comparison of crop rotation for Verticillium wilt management and effect on Pythium species in conventional and organic strawberry production. Plant Dis. 93:519-527.

O'Hara, R. B., and Kotze, D. J. 2010. Do not log transform count data. Methods Ecol. Evol. 1:118-122.

O'Sullivan, J. 1978. Effects of rotation and nitrogen on yield and quality of potatoes. Can. J. Plant Sci. 58:475-483. 
Ochiai, N., Powelson, M. L., Dick, R. P., and Crowe, F. J. 2007. Effects of green manure type and amendment rate on Verticillium wilt severity and yield of Russet Burbank potato. Plant Dis. 91:400-406.

Oksanen, J., Blanchet, F. G., Kindt, R., Legendre, P., Minchin, P. R., Simpson, G. L., Solymos, P., Stevens, M. H. H., and Wagner, H. 2013. Vegan: Community ecology package. R package version 2.0-7. http://vegan.r-forge. r-project.org/

Pegg, G. F., and Brady, B. L. 2002. Hosts. Pages 293-340 in: Verticillium Wilts. CABI Publishing, Wallingford, Oxon, UK.

Perry, J. W., and Evert, R. F. 1983. The effect of colonization by Verticillium dahliae on the root tips of Russet Burbank potatoes. Can. J. Bot. 61:34223429.

Perry, J. W., and Evert, R. F. 1984. Structure of microsclerotia of Verticillium dahliae in roots of 'Russet Burbank' potatoes. Can. J. Bot. 62:396-401.

Powelson, M. L., and Rowe, R. C. 1993. Biology and management of early dying of potatoes. Annu. Rev. Phytopathol. 31:111-126.

Robb, J., Lee, B., and Nazar, R. N. 2007. Gene suppression in a tolerant tomato-vascular pathogen interaction. Planta 226:299-309.

Rodriguez, R. J., and Roossinck, M. 2012. Viruses, fungi and plants: Crosskingdom communication and mutualism. Pages 219-227 in: Biocommunication of Fungi. G. Witzany, ed. Springer Science + Business Media, Dordrecht, Netherlands.

Rowe, R. C., and Powelson, M. L. 2002. Potato early dying: Management challenges in a changing production environment. Plant Dis. 86:1184-1193.

Schreiber, L. R., and Green, R. H. 1963. Effect of root exudates on germination of conidia and microsclerotia of Verticillium albo-atrum inhibited by soil fungistatic principle. Phytopathology 53:260-264.

Shaner, G., and Finney, R. E. 1977. The effect of nitrogen fertilization on the expression of slow-mildewing resistance in Knox wheat. Phytopathology 67:1051-1056
Shetty, K. G., Subbarao, K. V., Huisman, O. C., and Hubbard, J. C. 2000. Mechanism of broccoli-mediated Verticillium wilt reduction in cauliflower. Phytopathology 90:305-310.

Slattery, R. J. 1981. Inoculum potential of Verticillium-infested potato cultivars. Am. Potato J. 58:135-142.

Subbarao, K. V., Hubbard, J. C., and Koike, S. T. 1999. Evaluation of broccoli residue incorporation into field soil for Verticillium wilt control in cauliflower. Plant Dis. 83:124-129.

Subbarao, K. V., Kabir, Z., Martin, F. N., and Koike, S. T. 2007. Management of soilborne diseases in strawberry using vegetable rotation. Plant Dis. 91:964-972.

Vargas-Machuca, R., Martin, C., and Galindez, W. 1987. Recovery of Verticillium dahliae from weed plants in farmers' fields in Peru. Plant Dis. 71:756-758.

Veronese, P., Narasimhan, M. L., Stevenson, R. A., Zhu, J.-K., Weller, S. C., Subbarao, K. V., and Bressan, R. A. 2003. Identification of a locus controlling Verticillium disease symptom response in Arabidopsis thaliana. Plant J. 35: 574-587.

Wheeler, T. A., Bordovsky, J. V., Keeling, J. W., Mullinix, B. G., Jr., and Woodward, J. E. 2012. Effects of crop rotation, cultivars, and irrigation and nitrogen rate on Verticillium wilt of cotton. Plant Dis. 96:985-989.

Wiggins, B. E., and Kinkel, L. L. 2005. Green manures and crop sequences influence potato diseases and pathogen inhibitory activity of indigenous streptomycetes. Phytopathology 95:178-185.

Wilhelm, S. 1955. Longevity of Verticillium wilt fungus in the laboratory and field. Phytopathology 45:180-181.

Woolliams, G. E. 1966. Host range and symptomology of Verticillium dahliae in economic, weed and native plants in interior British Columbia. Can. J. Plant Sci. 46:661-669.

Xiao, C. L., Subbarao, K. V., Schulbach, K. F., and Koike, S. T. 1998. Effects of crop rotation and irrigation of Verticillium dahliae microsclerotia in soil and wilt in Cauliflower. Plant Dis. 88:1046-1055. 